\title{
Evaluation of Wound Healing Properties of Herbal Medicaments on the Basis of Clinical and Haemato-biochemical Changes
}

\author{
Neha Sharma ${ }^{1}$, Randhir Singh ${ }^{1 *}$, Apra Shahii ${ }^{1}$, R.K. Sharma ${ }^{2}$, Rakhi Vaish ${ }^{3}$ and R.K. Vandre ${ }^{4}$ \\ ${ }^{1}$ Department of Veterinary Surgery and Radiology, NDVSU, Jabalpur, (M.P.), INDIA \\ ${ }^{2}$ Department of Veterinary Pharmacology and Toxicology, NDVSU, Jabalpur, (M.P.), INDIA \\ ${ }^{3}$ Department of Veterinary Anatomy and Histology, NDVSU, Jabalpur, (M.P.), INDIA \\ ${ }^{4}$ Department of Animal genetics and breeding, NDVSU, Jabalpur, (M.P.), INDIA \\ *Corresponding author: R Singh; E-mail: randhirvet2k@rediffmail.com
}

Received: 25 July, 2019

Revised: 17 Aug., 2019

Accepted: 24 Aug., 2019

\begin{abstract}
The present study was conducted on 24 dogs irrespective of sex, breed and aged between 1year to 8 years with different types of wounds. The animals were randomly divided into four groups. Each group consisted of 6 dogs. The animals of group I were treated with povidone iodine (5.0\%) and in group II, III, IV animals were treated with the herbal ointment which were prepared from hydroalcoholic extract of Marigold leaves, Guava leaves and 1:1 mixture of both extract for 7 consecutive days. Clinical and haematological parameters were recorded at different time intervals in all four groups. The study revealed better wound healing properties of the Ointment of 1:1 mixture of Marigold and Guava $(10 \% \mathrm{w} / \mathrm{w})$ leaves extract without any side effect as compared to povidone iodine 5\%, ointment of Marigold leaves extract $(10 \% \mathrm{w} / \mathrm{w})$ and ointment of Guava leaves extract $(10 \%$ $\mathrm{w} / \mathrm{w})$ on the basis of clinical and haematological parameters.
\end{abstract}

Keywords: Dogs, Marigold and Guava leaves, Haematology and Biochemical

Wound healing is a biological process showing a definite pattern of cellular and molecular events which ultimately lead to repair of injured tissue. Marigold (Tagetes erecta), besides being an ornamental plant, have various medicinal properties. It is having nematocidal, fungicidal, antibacterial, insecticidal and wound healing properties (Dixit et al., 2013). Rajvanshi and Dwivedi (2017) reported that phytonutrients like terpenoids, alkaloids, flavonoids, quinines, carbohydrates and tannins are present in Tegetes erecta leaves extract. These compounds were found to have valuable antifungal, antibacterial and anti-inflammatory properties.

Arya et al. (2012) performed preliminary phytochemical screening of Psidium guajava leaves extract that showed the presence of flavonoids, tannins, terpenoids, saponins, sterols, and carbohydrates in its hydro alcoholic extract. Guava (Psidium guajava) is used medicinally in many parts of the world as an anti inflammatory and antiseptic as well as in the treatment of wound, diabetes, hypertension, pain, fever, respiratory disorders, gastroenteritis, diarrhoea and dysentery (Fernandes et al., 2010).

Therefore, the present study was planned to compare the wound healing properties of Povidone iodine 5.0\%, hydroalcoholic extract of Marigold leaves $(10 \% \mathrm{w} / \mathrm{w})$, hydroalcoholic extract of Guava leaves $(10 \% \mathrm{w} / \mathrm{w})$ and a 1:1 mixture of hydroalcoholic extract of combination of both leaves of Marigold (10\% w/w) and Guava $(10 \% \mathrm{w} / \mathrm{w})$ on the basis of clinical and haemato-biochemical changes.

\section{MATERIALS AND METHODS}

The study was conducted in Department of Veterinary Surgery and Radiology, College of Veterinary Science and

How to cite this article: Sharma N., Singh, R., Shahi, A., Sharma, R.K. Vaish, R. and Vandre, R.K. (2020). Evaluation of wound healing properties of herbal medicaments on the basis of clinical and haemato-biochemical changes. J. Anim. Res., 10(1): 157-162. 
Animal Husbandry, Nanaji Deshmukh Veterinary Science University, Jabalpur, M.P.

\section{Animals}

The study was conducted on 24 dogs, irrespective of sex, breed and age between 1-8 years. These dogs were randomly divided into four groups and each group was having 6 dogs.

\section{Animal ethics}

Present study was approved from Institutional Animal Ethical Committee (No. 81/IAEC/Vety/2017; dated: 08/08/2017).

\section{Extraction method}

The leaves were collected from plant Tegetes erecta and Psidium guajava of the local area. Leaves were grinded after the cleaning in water and air dry. $75 \mathrm{~g}$ powder of leaves was packed into thimble and put in a Soxhlet apparatus and extracted with $500 \mathrm{ml}$ of hydro alcoholic solvent ( $350 \mathrm{ml}$ ethanol $95 \%$ and $150 \mathrm{ml}$ water) at $65{ }^{\circ} \mathrm{C}$ to $70^{\circ} \mathrm{C}$ for $24 \mathrm{~h}$ (Chatterjee et al., 2011). For preparation of ointment $(10 \% \mathrm{w} / \mathrm{w}), 5 \mathrm{~g}$ of dry powder of each Marigold and Guava hydroethanolic extract separately mixed in 45 $\mathrm{g}$ white petroleum gelly base individually. Mixed ointment $(10 \% \mathrm{w} / \mathrm{w})$ was prepared with $2.5 \mathrm{~g}$ of dry powder extract of Marigold, $2.5 \mathrm{~g}$ of dry powder extract of Guava and 45 $\mathrm{g}$ white petroleum jelly and mixed properly.

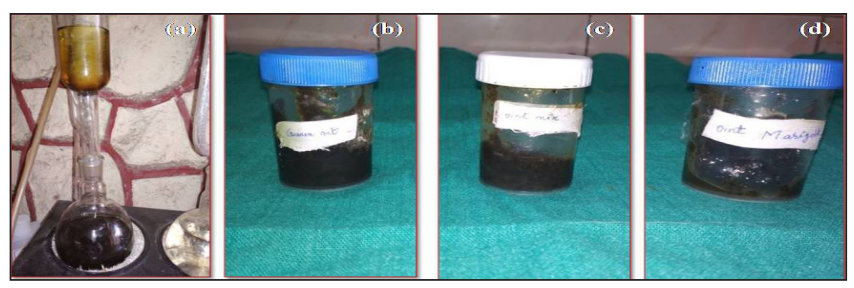

Fig. 1: Photograph showing (a) Extraction of extract in Soxhlet apparatus (b) Guava ointment $10 \% \mathrm{w} / \mathrm{w}$ (c) Mix ointment $10 \% \mathrm{w} / \mathrm{w}$ and (d) Marigold ointment $10 \% \mathrm{w} / \mathrm{w}$

\section{Treatment design}

Twenty dogs were included in the present study and randomly divided into four equal groups. First of all, the wounds were gently cleaned with normal saline. The treatment design is mentioned below:
Table 1: Treatment design

\begin{tabular}{cc}
\hline $\begin{array}{c}\text { Treatment } \\
\text { Groups }\end{array}$ & Dressing material \\
\hline Group I & $\begin{array}{c}\text { Povidone iodine }(5.0 \%) \\
\text { Group II }\end{array}$ \\
& $\begin{array}{c}\text { Ointment of Tegetes erecta }(\text { Marigold) leaves } \\
\text { extract }(10 \% \mathrm{w} / \mathrm{w})\end{array}$ \\
Group III & Ointment of Psidium guajava $($ Guava) leaves \\
& $(10 \% \mathrm{w} / \mathrm{w})$
\end{tabular}

\section{Observations}

Complete history of the cases was recorded including age, sex, and breed, type of wound and duration of wound.

Degree of inflammation and degree of exudation were graded and scored on the basis of arbitrary score card (Bhowmick, 2014) on day 0, 7, 14, 21, 28 by marked oedema, erythema, inflammation, pain and exudate. Haemato-biochemical parameters viz. total erythrocyte count (TEC), haemoglobin ( $\mathrm{Hb})$, packed cell volume, total leukocyte count (TLC), differential leukocyte count (DLC) and total protein (TP) were studied on day 0, 7, 14. Wound healing parameters such as percentage of wound re-epithelialization and wound healing percentage also were studied on day 3, 7 and 14 as per the described method of Kumar and Tyagi (1972).

\section{RESULTS AND DISCUSSION}

During the study period, the highest occurrence of bite wounds $(33.33 \%)$ was recorded in non-descript dogs $(62.5 \%)$ in age group of $3-5$ years $(45.83 \%)$ and in males (53.34\%). There are many factors those are responsible for the occurrence of wounds such as higher population of non-descript dogs in local area, influence of male sex hormone, nutrient deficiency etc.

\section{Degree of inflammation and degree of exudation}

First phase of wound healing is inflammatory phase and this phase takes maximum 7 days in normal wound healing. But in case of infected, chronic wounds, bite wounds, severe injury or other factors those are responsible for decrease wound healing process continue for longer 
duration. On day 7, inflammation and exudation were found significantly decreased in all groups. In group II and IV, no inflammation was observed from day 14 onwards, no exudation was observed from day 14 onwards in group IV. It may be due to the analgesic and inflammatory activity of tannin and flavonoid phytochemicals in Marigold leaf extract. However, mixed ointment (Marigold and Guava extract) also showed better reduction in inflammation and exudation on wound site due to the higher concentration of different phytochemicals as compared to single extract (Table 2).

\section{Haemato-biochemical parameters}

Phytochemical analyses indicated that leaf extracts contains chemical compounds such as alkaloids, tannins, anthraquinone, cardenolides, steroids, saponins, phenolics, reducing sugars, flavonoids and cardiac glycosides. These compounds can affect various biological processes in the body in ways that might have harmful or beneficial effects and also have an important role in wound healing process. So these parameters were studied to monitor the changes during and after the treatment.

\section{Haemoglobin and packed cell volume}

The mean haemoglobin concentration and packed cell volume showed non-significant difference between the groups. The mean haemoglobin and packed cell volume concentration significantly $(p<0.05)$ increased on day 7 onwards up to the day 14 in groups II and III. Haemoglobin values and packed cell volume were slightly higher in group II and III, it may be due to variation in physical status of animals (Table 3 ). Topical application of medicines did not influence the haemoglobin much (Singh et al., 2016).

\section{Total erythrocyte count and total leukocyte count}

The mean value of total erythrocyte count and total leukocyte count varied non-significantly between the groups and within the groups. Basha et al. (2011), Singh et al. (2016) reported non-significant variation in total erythrocyte count and total leukocyte count in wounds of dogs. An increase in total erythrocyte count at day 7 onwards may be due to return of normal physiological status of animal after trauma and topically applied

Table 2: Degree of inflammation and degree of exudation at different time intervals

\begin{tabular}{ccccccccc}
\hline & \multicolumn{4}{c}{ Degree of inflammation } & \multicolumn{3}{c}{ Degree of Exudation } \\
\hline Groups & I & II & III & IV & I & II & III & IV \\
\hline Day 0 & $2.64^{\mathrm{a}} \pm 0.06$ & $2.50^{\mathrm{a}} \pm 0.00$ & $2.50^{\mathrm{a}} \pm 0.00$ & $2.50^{\mathrm{a}} \pm 0.00$ & $3.00^{\mathrm{a}} \pm 0.00$ & $3.00^{\mathrm{a}} \pm 0.00$ & $2.00^{\mathrm{a}} \pm 0.00$ & $2.83^{\mathrm{a}} \pm 0.16$ \\
Day 7 & $1.46^{\mathrm{ab}} \pm 0.21$ & $1.50^{\mathrm{b}} \pm 0.00$ & $0.86^{\mathrm{b}} \pm 0.09$ & $1.24^{\mathrm{b}} \pm 0.09$ & $2.50^{\mathrm{b}} \pm 0.00$ & $2.50^{\mathrm{b}} \pm 0.00$ & $2.00^{\mathrm{b}} \pm 0.00$ & $1.50^{\mathrm{b}} \pm 0.00$ \\
Day 14 & $0.86^{\mathrm{bc}} \pm 0.09$ & $0.00^{\mathrm{c}} \pm 0.00$ & $0.94^{\mathrm{b}} \pm 0.12$ & $0.00^{\mathrm{c}} \pm 0.00$ & $0.83^{\mathrm{c}} \pm 0.16$ & $0.33^{\mathrm{c}} \pm 0.21$ & $0.50^{\mathrm{c}} \pm 0.22$ & $0.00^{\mathrm{c}} \pm 0.00$ \\
Day 21 & $0.00^{\mathrm{c}} \pm 0.00$ & $0.00^{\mathrm{c}} \pm 0.00$ & $0.00^{\mathrm{c}} \pm 0.00$ & $0.00^{\mathrm{c}} \pm 0.00$ & $0.00^{\mathrm{d}} \pm 0.00$ & $0.00^{\mathrm{d}} \pm 0.00$ & $0.00^{\mathrm{d}} \pm 0.00$ & $0.00^{\mathrm{d}} \pm 0.00$ \\
Day 28 & $0.00^{\mathrm{c}} \pm 0.00$ & $0.00^{\mathrm{c}} \pm 0.00$ & $0.00^{\mathrm{c}} \pm 0.00$ & $0.00^{\mathrm{c}} \pm 0.00$ & $0.00^{\mathrm{d}} \pm 0.00$ & $0.00^{\mathrm{d}} \pm 0.00$ & $0.00^{\mathrm{d}} \pm 0.00$ & $0.00^{\mathrm{d}} \pm 0.00$ \\
\hline
\end{tabular}

Mean values within treatment group with different superscript varied significantly $(\mathrm{p}<0.05)$.

Table 3: Haemoglobin (g/dl) and packed cell volume (\%) at different time intervals

\begin{tabular}{ccccccccc}
\hline \multicolumn{9}{c}{ Haemoglobin } \\
\hline Groups & I & II & III & IV & I & II & III & IV \\
\hline 0 & $10.35^{\mathrm{a}} \pm 0.29$ & $9.68^{\mathrm{b}} \pm 0.28$ & $10.00^{\mathrm{b}} \pm 0.25$ & $10.07^{\mathrm{a}} \pm 0.20$ & $32.00^{\mathrm{a}} \pm 1.60$ & $34.77^{\mathrm{b}} \pm 1.47$ & $30.17^{\mathrm{b}} \pm 1.56$ & $30.65^{\mathrm{a}} \pm 1.68$ \\
7 & $10.08^{\mathrm{a}} \pm 0.27$ & $10.65^{\mathrm{ab}} \pm 0.34$ & $10.29^{\mathrm{b}} \pm 0.25$ & $10.15^{\mathrm{a}} \pm 0.23$ & $31.67^{\mathrm{a}} \pm 1.02$ & $35.37^{\mathrm{a}} \pm 1.78$ & $32.43^{\mathrm{b}} \pm 1.52$ & $31.71^{\mathrm{a}} \pm 1.78$ \\
14 & $10.57^{\mathrm{a}} \pm 0.27$ & $11.16^{\mathrm{a}} \pm 0.34$ & $10.75^{\mathrm{a}} \pm 0.19$ & $10.67^{\mathrm{a}} \pm 0.12$ & $34.16^{\mathrm{a}} \pm 1.32$ & $337.12^{\mathrm{a}} \pm 1.787$ & $34.65^{\mathrm{a}} \pm 1.48$ & $33.03^{\mathrm{a}} \pm 1.68$ \\
\hline
\end{tabular}

Mean values within treatment group with different superscript varied significantly $(\mathrm{p}<0.05)$. 
Table 4: Total erythrocyte count and Total leukocyte count at different time intervals

\begin{tabular}{cccccccccc}
\hline & \multicolumn{3}{c}{ Total erythrocyte count } & & \multicolumn{3}{c}{ Total leukocyte count } \\
\hline Groups & I & II & III & IV & I & II & III & IV \\
\hline 0 & $5.95 \pm 0.08$ & $5.90 \pm 0.05$ & $5.61 \pm 0.10$ & $5.95 \pm 0.07$ & $14.29 \pm 1.44$ & $17.05 \pm 1.68$ & $16.95 \pm 1.72$ \\
7 & $6.02 \pm 0.08$ & $6.05 \pm 0.03$ & $5.71 \pm 0.10$ & $5.85 \pm 0.15$ & $11.48 \pm 1.29$ & $12.55 \pm 1.60$ & $12.57 \pm 1.48$ & $11.05 \pm 1.41$ & $14.63 \pm 1.72$ \\
14 & $6.04 \pm 0.08$ & $6.05 \pm 0.03$ & $6.08 \pm 0.18$ & $6.05 \pm 0.01$ & $11.03 \pm 1.39$ & $12.10 \pm 1.67$ & $12.57 \pm 1.38$ & $10.93 \pm 1.27$ \\
\hline
\end{tabular}

Table 5: Neutrophil percent and lymphocyte percent at different time intervals

\begin{tabular}{cccccccccccc}
\hline & \multicolumn{4}{c}{ Neutrophil percent } & \multicolumn{3}{c}{ Lymphocyte percent } \\
\hline Groups & I & II & III & IV & I & II & III & IV \\
\hline Day 0 & $76.83^{\mathrm{a}} \pm 0.60$ & $75.83^{\mathrm{a}} \pm 1.01$ & $74.83^{\mathrm{a}} \pm 0.40$ & $76.00^{\mathrm{a}} \pm 0.78$ & $18.33^{\mathrm{b}} \pm 0.80$ & $19.67^{\mathrm{c}} \pm 0.61$ & $19.17^{\mathrm{c}} \pm 0.74$ & $18.66^{\mathrm{c}} \pm 0.71$ \\
Day 7 & $73.16^{\mathrm{b}} \pm 0.94$ & $70.50^{\mathrm{b}} \pm 0.61$ & $70.50^{\mathrm{b}} \pm 0.71$ & $72.50^{\mathrm{b}} \pm 1.20$ & $23.17^{\mathrm{a}} \pm 1.01$ & $27.67^{\mathrm{b}} \pm 0.98$ & $26.83^{\mathrm{a}} \pm 1.01$ & $22.33^{\mathrm{b}} \pm 1.09$ \\
Day 14 & $69.17^{\mathrm{c}} \pm 1.25$ & $67.17^{\mathrm{c}} \pm 1.17$ & $66.83^{\mathrm{c}} \pm 1.01$ & $66.17^{\mathrm{c}} \pm 0.60$ & $25.83^{\mathrm{a}} \pm 1.14$ & $23.50^{\mathrm{c}} \pm 0.76$ & $24.67^{\mathrm{b}} \pm 0.50$ & $26.17^{\mathrm{a}} \pm 0.70$ \\
\hline
\end{tabular}

Mean values within treatment group with different superscript varied significantly $(\mathrm{p}<0.05)$.

medicines having no effect on total leukocyte count (Table 4).

\section{Differential leukocyte count}

\section{Neutrophil percent}

The mean values of neutrophil was found to be significantly $(p<0.05)$ decreased at day 7 in comparison to day 0 , then after a significant $(\mathrm{p}<0.05)$ decrease was recorded at day 14 in all the group. Mostly neutrophilic infiltration lasts for a couple of days and decline towards later part of inflammation. All medicaments were effective to subside inflammatory response.

\section{Lymphocyte percent}

The mean lymphocyte count was found to be significantly $(p<0.05)$ higher at day 7 in comparison to 0 day in all groups. Thereafter, it increased significantly $(p<0.05)$ on 14 day in group I and IV, but it was within physiological range (Table 5). Lymphocytes are not required for the initiation of wound healing, but an intact cellular immune response is essential for a normal outcome of tissue repair which is indicative of better immune response in these groups of animals Schaffer and Barbul (1998).

\section{Monocytes percent and eosinophil percent}

The mean value of monocytes per cent and eosinophils percent varied non significantly between the groups. In all the groups, the mean value of monocyte count was found to be significantly $(\mathrm{p}<0.05)$ decreased at day 7 in comparison to day 0 . Then, it increased significantly $(p<0.05)$ on day 14 , but it was within physiological range. Monocytosis may be associated with chronic inflammation, bacteremia corticosteroids or stress response.

Mean values of eosinophil count varied from $2.16 \pm 0.30$ to $3.67 \pm 0.21$ at different time intervals in all groups. The mean eosinophil count was found to be significantly $(p<0.05)$ increased at day 7 in comparison to 0 day in group III and IV. Thereafter, it decreased significantly $(p<0.05)$ on day 14 onwards. In present study, the eosinophil count might be increased transiently (Table 6). Increase in eosinophil count could be associated with skin allergies, anaphylactic reaction and parasitism.

\section{Total serum protein}

The mean value of total serum protein varied non significantly between the groups and within the groups. The rate of wound healing is not correlated with serum protein further the change in serum protein level was within normal physiological range (Table 7).

\section{Wound healing and wound re-epithelialization percent}

The mean value of wound healing per cent and wound re-epithelialization per cent were significantly $(p<0.05)$ higher in group IV in comparison to other groups (Table 
Table 6: Monocyte percent and eosinophil percent at different time intervals

\begin{tabular}{|c|c|c|c|c|c|c|c|c|}
\hline \multirow[b]{2}{*}{ Groups } & \multicolumn{4}{|c|}{ Monocyte percent } & \multicolumn{4}{|c|}{ Eosinophil percent } \\
\hline & I & II & III & IV & I & II & III & IV \\
\hline Day 0 & $2.50^{\mathrm{a}} \pm 0.22$ & $2.33^{\mathrm{a}} \pm 0.21$ & $3.08^{\mathrm{a}} \pm 0.48$ & $3.00^{\mathrm{ab}} \pm 0.52$ & $2.33^{\mathrm{a}} \pm 0.31$ & $2.16^{\mathrm{a}} \pm 0.40$ & $2.33^{b} \pm 0.33$ & $2.23^{b} \pm 0.26$ \\
\hline Day 7 & $1.67^{\mathrm{b}} \pm 0.33$ & $1.33^{\mathrm{b}} \pm 0.33$ & $1.66^{\mathrm{b}} \pm 0.33$ & $2.00^{\mathrm{b}} \pm 0.36$ & $2.50^{\mathrm{a}} \pm 0.34$ & $2.67^{\mathrm{a}} \pm 0.33$ & $2.83^{\mathrm{b}} \pm 0.16$ & $3.67^{\mathrm{a}} \pm 0.21$ \\
\hline Day 14 & $2.50^{\mathrm{a}} \pm 0.22$ & $2.83^{\mathrm{a}} \pm 0.30$ & $3.75^{\mathrm{a}} \pm 0.22$ & $4.00^{\mathrm{a}} \pm 0.36$ & $2.16^{\mathrm{a}} \pm 0.30$ & $2.23^{\mathrm{a}} \pm 0.03$ & $2.83^{\mathrm{a}} \pm 0.17$ & $2.83^{\mathrm{ab}} \pm 0.31$ \\
\hline
\end{tabular}

Mean values within treatment group with different superscript varied significantly $(\mathrm{p}<0.05)$.

Table 7: Total serum protein $(\mathrm{g} / \mathrm{dl})$ at different time intervals

\begin{tabular}{ccccc}
\hline Groups & I & II & III & IV \\
\hline Day 0 & $5.65 \pm 0.08$ & $5.41 \pm 0.10$ & $5.61 \pm 0.09$ & $5.68 \pm 0.17$ \\
Day 7 & $5.53 \pm 0.08$ & $5.71 \pm 0.12$ & $5.78 \pm 0.08$ & $5.85 \pm 0.15$ \\
Day 14 & $5.71 \pm 0.07$ & $6.21 \pm 0.21$ & $6.63 \pm 0.18$ & $6.14 \pm 0.14$ \\
\hline
\end{tabular}

Table 8: Wound healing (\%) and re-epithelialization per cent at different time intervals

\begin{tabular}{|c|c|c|c|c|c|c|c|c|}
\hline & \multicolumn{4}{|c|}{ Wound healing per cent } & \multicolumn{4}{|c|}{ Re-epithelialization per cent } \\
\hline Groups & I & II & III & IV & $\mathbf{I}$ & II & III & IV \\
\hline Day 3 & $9.73^{\mathrm{CB}_{ \pm} 2.26}$ & $10.51^{\mathrm{cB}} \pm 0.84$ & $10.56^{\mathrm{cB}} \pm 0.89$ & $16.56^{\mathrm{cA}} \pm 0.54$ & $5.33^{\mathrm{cC}} \pm 0.86$ & $16.72^{\mathrm{bB}} \pm 3.00$ & $16.83^{\mathrm{bB}} \pm 2.80$ & $20.03^{\mathrm{bA}} \pm 3.38$ \\
\hline Day 7 & $29.84^{\mathrm{bB}} \pm 4.85$ & $41.22^{\mathrm{bA}} \pm 1.62$ & $41.39^{\mathrm{bA}} \pm 1.57$ & $51.17^{\mathrm{bA}} \pm 1.14$ & $19.41^{\mathrm{bC}} \pm 0.58$ & $23.01^{\mathrm{aB}} \pm 0.77$ & $23.50^{\mathrm{aB}} \pm 0.74$ & $26.30^{\mathrm{bA}} \pm 2.29$ \\
\hline Day 14 & $64.87^{\mathrm{aC}_{ \pm}} .37$ & $80.95^{\mathrm{aB}} \pm 0.88$ & $81.23^{\mathrm{aB}} \pm 0.95$ & $92.90^{\mathrm{cA}} \pm 0.67$ & $21.53^{\mathrm{aC}} \pm 0.61$ & $25.8^{\mathrm{aB}} \pm 0.97$ & $25.80^{\mathrm{aB}} \pm 0.97$ & $36.18^{\mathrm{aA}} \pm 2.23$ \\
\hline
\end{tabular}

Mean values within treatment group and between the groups with different superscript varied significantly $(\mathrm{p}<0.05)$.

8). Combined extract of different plant leaves was having synergistic effect of different phytochmicals such as tannin and flavonoids on wound healing and better results were seen in comparison to single component. The combined ointment of Marigold and Guava leaves in ratio of 1:1 (w/w) showed higher percentage of wound re-epithelialization and wound healing percentage than remaining groups (Fig. 2 and 3).
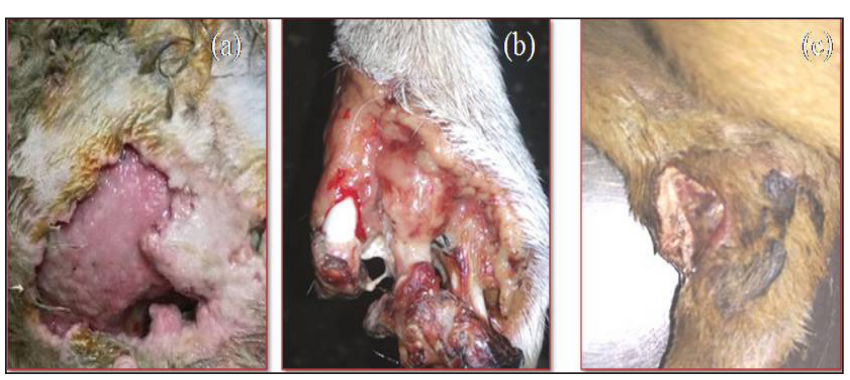

Fig. 2: Photograph showing degree of healing on day 0 (a) Marigold ointment (b) Guava ointment (c) Mix ointment

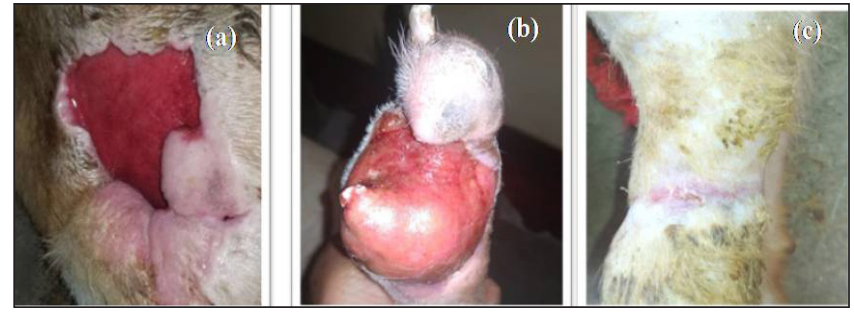

Fig. 3: Photograph showing degree of healing on day 28 (a) Marigold ointment (b) Guava ointment (c) Mix ointment

\section{CONCLUSION}

$10 \% \mathrm{w} / \mathrm{v}$ ointment of 1:1 mixture of Marigold and Guava leaves extract revealed better wound healing properties without any adverse changes in haemato-biochemical parameters as compared to povidone iodine $5 \%$, ointment of Marigold leaves extract $(10 \% \mathrm{w} / \mathrm{w})$ and ointment of Guava leaves extract $(10 \% \mathrm{w} / \mathrm{w})$. 
CONFLICT OF INTEREST: All authors declare no conflict of interest.

\section{REFERENCES}

Basha, S.K., Kumar, R.S., Haragopal, V., Srilatha, C., Sastry, T.P. and Vidyavathi, M. 2011. Effects of fish scales extracted collagen biocastings on cutaneous wound healing in dogs. Res. J. Pharmceu. Biol. Chem. Sci, 2: 36-49.

Bhowmick, D. 2014. Biostimulation of clinical wound by cold laser irradiation in bovine. Ph.D. thesis (Surgery and Radiology), Nanaji Deshmukh Veterinary Science University, Jabalpur, pp. 45-53.

Chatterjee, S., Prakash, T., Kotrsha, D., Rao, N.R. and Goli, D. 2011. Comparative efficacy of Tegetes erecta and Centella asiatica extract on wound healing in albino rats. Chin. Med., 2: $138-142$

Dixit, P., Tripathi S. and Verma, N.K. 2013. A brief study on marigold (Tagetes species): a review. Int. Res. J. Pharma., 4: 43-48.

Arya, V., Thakur, N. and Kashyap, C.P. 2012. Preliminary phytochemical analysis of the extracts of Psidium spp. leaves. J. Pharmacogn. Phytochem., 1(1): 1-5.
Fernandes, K.P.S., Bussadori, S.K., Marques, M.M., Wadt, N.S.Y., Bach, E. and Martins, M.D. 2010. Healing and cytotoxic effects of Psidium guajava (Myrtaceae) leaf extracts. Braz. J. Ora. Sci., 9: 449-454.

Kumar, R. and Tyagi, R.P.S. 1972. A Study on some factor influencing wound healing and the effect of various cleansing and debriding agents on the rate of epithelium healing in the buffalo calf. Hary. Agri. Uni. J. Res., 2(1): 206-212.

Rajvanshi, S.K. and Dwivedi, D.H. 2017. Phytochemical screening studies of bioactive compounds of African marigold (Tagetes erecta L.). J. Pharmacogn. Phytochem., 6(4): 524527.

Schaffer, M. and Barbul, A. 1998. Lymphocyte function in wound healing and following injury. BJS Open., 85: 444-460.

Singh, Y., Shukla, B.P., Jain, R. and Jaiswal, A. 2016. Comparative evaluation of haemato-biochemical changes during infected wound healing in cow calves with the use of silver nano particle gel and povidone iodine. Vet. Pract., 18: 54-55. 